\title{
Contrasting Population Trends at Two Razorbill Colonies in Atlantic Canada: Additive Effects of Fox Predation and Hunting Mortality?
}

\section{Comparaison de la tendance de deux colonies de Petits Pingouins dans les provinces de l'Atlantique : la prédation par le renard et la mortalité par la chasse ont-elles un effet cumulatif?}

\author{
$\underline{\text { Jennifer L. Lavers }}^{1,2}$ Ian L. Jones $^{1}{ }^{1 \text { Gregory J. Robertson }}{ }^{3}$, and Antony W. Diamond $^{4}$
}

\begin{abstract}
We developed a stochastic, stage-based, matrix-projection population model to assess population viability and estimate the impact of mortality caused by hunting, illegal and incidental to the murre (Uria sp.) hunt, and fox (Alopex lagopus) predation on Razorbill (Alca torda) populations breeding on the Gannet Islands, Labrador, the "affected" population, and Machias Seal Island, New Brunswick, the "unaffected" population. We estimated the potential population growth rate in the absence of anthropogenic mortality sources by using juvenile survival estimates from the relatively unaffected Machias Seal Island Razorbill population. We used data collected on fox predation on the Gannet Islands from 1978-2009 to estimate the change in productivity as a result of fox presence. The intrinsic growth rate $(\lambda)$ of the stochastic matrix based on vital rates from the Gannet Islands was $0.957 \pm 0.008$ and $1.058 \pm 0.005$ for Machias Seal Island. Hunting mortality reduced the predicted Gannet Islands population growth rate by 0.033 , while fox predation reduced population growth rate by 0.017 . These sources combined reduced the baseline population growth rate by 0.050 . According to our model, the Razorbill population on Machias Seal Island appears to be growing rapidly. In contrast, the Gannet Islands population may decline, likely because of hunting. However, oceanographic differences between the two areas and uncertainty regarding dispersal behavior in this species may also contribute to the disparity between populations. Based on our findings, we make several recommendations for the conservation and management of Razorbills in Atlantic Canada.
\end{abstract}

RÉSUMÉ. Nous avons développé un modèle stochastique matriciel afin d'évaluer la viabilité des populations et d'estimer l'impact de la mortalité attribuable aux prises illégales ou accidentelles au moment de la chasse aux guillemots (Uria sp.) ainsi que l'impact de la prédation par le renard arctique (Alopex lagopus) sur le Petit Pingouin (Alca torda). Deux populations de Petits Pingouins ont été comparées : une touchée par la chasse et la prédation sur les îles Gannet au Labrador, et l'autre, non touchée, sur l'île Machias Seal au Nouveau-Brunswick. Nous avons estimé le taux de croissance potentiel de la population en l'absence de sources de mortalité anthropogénique à l'aide d'estimations de la survie des jeunes provenant de la colonie de Petits Pingouins de l'île Machias Seal. Nous avons utilisé les données de prédation par le renard arctique sur les îles Gannet de 1978 à 2009 afin d'estimer la variation de la productivité en fonction de la présence du renard. Le taux de croissance intrinsèque $(\lambda)$ de la matrice stochastique, fondée sur les

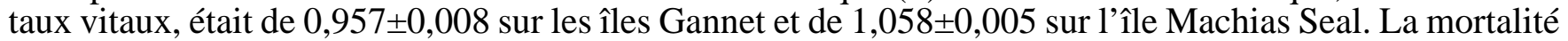
attribuée à la chasse a réduit de 0,033 le taux de croissance prédit pour la population des îles Gannet, tandis que la prédation par le renard l'a réduit de 0,017. Ces deux sources de mortalité combinées ont réduit de 0,050 le taux de croissance de la population. Selon notre modèle, il semble que la population de Petits Pingouins de l'île Machias Seal croisse rapidement. À l'opposé, il se peut que la population des îles Gannet décroisse, vraisemblablement à cause de la chasse. Toutefois, les conditions océanographiques différentes

\footnotetext{
${ }^{1}$ Department of Biology, Memorial University of Newfoundland,

${ }^{2}$ Department of Zoology, University of Tasmania, ${ }^{3}$ Canadian Wildlife

Service, ${ }^{4}$ Atlantic Cooperative Wildlife Ecology Research Network,

University of New Brunswick
}

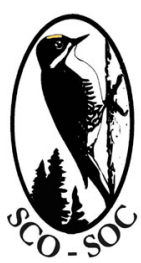

Sponsored by the Society of Canadian Ornithologists and Bird Studies Canada

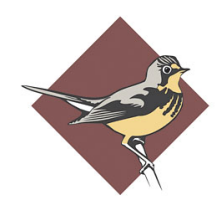


entre les deux endroits et le comportement de dispersion incertain chez cette espèce contribuent peut-être également à la différence observée entre les deux populations. À partir des résultats obtenus, nous proposons des recommandations pour la conservation et la gestion du Petit Pingouin dans les provinces de l'Atlantique.

Key Words: Alca torda; anthropogenic mortality; fox predation; hunting; population dynamics; Razorbill

\section{INTRODUCTION}

Understanding the life-history strategies and responses of organisms to natural and anthropogenic mortality is essential to the proper management of populations. The ability to quickly detect adverse changes to populations and determine the possible cause is critical, but challenging in some species (Croxall and Rothery 1991). In seabirds, extended at-sea periods and movement among sites can make it difficult to detect changes in population size and survival. Because even small changes in adult survival can have large effects on the lifetime reproductive success of individuals and populations as a whole (Merkel 2004, Sandvik et al. 2005), identifying the factors responsible for population declines is a key objective of conservation-oriented studies. To do this, researchers are turning increasingly to demographic models that identify key life stages or sources of mortality influencing populations (Lebreton and Clobert 1991, McDonald and Caswell 1993). Such models can also be used to assess the effectiveness of different management strategies and to guide future research. For seabirds, models have been developed to address issues such as mortality in fisheries, hunting, and introduced predators (Hamilton and Moller 1995, Cuthbert et al. 2001, Velando and Freire 2002).

Most seabirds breed on remote islands and, as such, have few terrestrial predators other than man (Larson 1960, Lack 1968, Croxall and Rothery 1991). However, at high latitudes, native mammalian predators such as Arctic foxes (Alopex lagopus) are able to reach some islands by traveling over pack ice (Larson 1960, Birkhead and Nettleship 1995). The presence of even a single fox around some bird nesting areas has resulted in delayed and asynchronous breeding and, in many cases, complete abandonment of the breeding site (Larson 1960, Southern et al. 1985, Birkhead and Nettleship 1995, Ratcliffe et al. 2000, Samelius and Alisauskas 2001). The Gannet Islands, Labrador, Canada, are home to the most diverse seabird colony in Labrador and harbor the largest breeding population of Razorbill (Alca torda) in North America, numbering 9800 pairs (Chapdelaine et al. 2001). On the Gannet Islands, most Razorbills breed in low-lying crevices and under boulders that are accessible to Arctic foxes. For years in which foxes were present, only a few individuals nesting on steep, inaccessible cliffs and ledges bred successfully (Birkhead and Nettleship 1995, Rowe and Jones 2000). Birkhead and Nettleship (1995) quantified the level of predation by foxes and response of Razorbills to their presence on the Gannet Islands. However, the effects of repeated years of fox predation and reproductive failure on the long-term status of Razorbill breeding in the icy waters at the northern part of their North American breeding range remains unknown.

In Newfoundland and Labrador, hunting of seabirds for sustenance and recreation is a longstanding tradition, but has been a significant threat to some populations (Blanchard 1984, Chardine et al. 2008). In recent years (1995-2003), from September to March, 150 000-200 000 Common Murre (Uria aalge) and Thick-billed Murre (Uria lomvia) are legally hunted by residents of Newfoundland and Labrador (Canadian Wildlife Service, unpublished data), a reduction from the 350000 or more taken in the 1970s and 1980s (Elliot 1991). Under the Canadian Migratory Birds Convention Act, Razorbills are classified as a nongame species, so there is no open hunting season, although take is permitted by the northern aboriginal Inuit people (Chapdelaine et al. 2001, Chardine et al. 2008). However, due to their close resemblance to the murres, many hundreds to thousands of Razorbills are accidentally or deliberately shot each year (Elliot 1991, Chapdelaine 1997, Chardine et al. 2008). Razorbills taken in this hunt come from colonies in Newfoundland and Labrador and Quebec (Chapdelaine 1997, Wilhelm et al. 2008). The North American Razorbill population is small, numbering less than 38000 pairs (Chapdelaine et al. 2001), and has declined historically in many parts 
of its range as a result of hunting, egging, and disturbance to breeding colonies (Blanchard 1984, Nettleship and Evans 1985). During the 1980s and 1990s, Razorbill populations in North America appeared to be increasing (Robertson and Elliot 2002, Robertson et al. 2002). However, recent census data are lacking, especially in Newfoundland and Labrador, and demographic studies conducted on the Gannet Islands suggest that population parameters, including productivity, measured as the mean number of young fledged per pair, and adult survival, have declined in recent years (Lavers and Jones 2007, Lavers et al. 2008b). Here, we develop a population model to simultaneously assess the relative and cumulative effects of hunting mortality, sporadic but widespread failure due to fox predation, and an apparent decline in overall productivity. We then use this model to evaluate the status of the Gannet Islands Razorbill population in relation to the relative and cumulative effects of mortality due to fox predation and hunting bycatch, that is, the accidental or deliberate shooting of Razorbills during activities directed at other species. We then compare the results with a Razorbill population that is unaffected by foxes or hunting and that breeds at the southern edge of the species' range on Machias Seal Island, New Brunswick, Canada.

\section{METHODS}

\section{Study Sites}

Demographic data were collected on five of the six islands in the Gannet Islands cluster (53 $56^{\prime}$ N, $56^{\circ}$

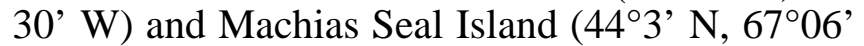
W) from 1995-2008 in connection with a long-term study on the survival and status of Atlantic Canadian Razorbill populations. From approximately December-March, the waters surrounding the Gannet Islands are almost completely covered in pack ice (Canadian Ice Service 2006). The waters surrounding Machias Seal Island, a small island located approximately $10 \mathrm{~km}$ off the coast of Maine that is home to approximately 550 Razorbill pairs (Grecian 2005), are ice free year round. Although we did not measure movement probabilities explicitly, we conducted intermittent resighting during 2003-2006 on the Herring Islands, Labrador $\left(54^{\circ} 20^{\prime} \mathrm{N}, 5^{\circ} 7^{\prime} \mathrm{W}\right.$ ) and on Petit Manan Island, Seal Island, and Matinicus Rock in the Gulf of

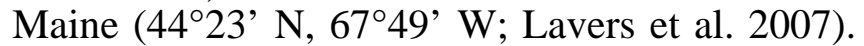
This was done to identify marked individuals that had moved away from the main study colonies, thus improving the accuracy of our survival estimates (Lavers et al. 2008b).

\section{Egg-Count Data}

Starting in 1978 and completed by 1999, 11 permanent monitoring plots were established on five islands (labeled GC1-5) in the Gannet Islands (Robertson and Elliot 2002). Each plot was delineated by natural features and stakes and carefully mapped. Each plot was thoroughly searched during the incubation period (mid July) and all Razorbill eggs were counted. These plots have been monitored somewhat sporadically since their establishment.

Egg counts were analyzed with negative binomial regressions to estimate trend $(\lambda)$, with plot included as a random effect, or subject, using PROC GENMOD in SAS (SAS Institute Inc. 2004). The dispersion parameter was left unconstrained during the estimation procedure. Three estimates of trend were calculated. These were the historical trend from 1978-1999, the recent trend from 1998-2007, and the overall trend spanning 1978-2007.

\section{Mortality Due to Foxes}

We used records of fox presence on the Gannet Islands from 1978-2009 to estimate the probability that a fox will be present on one or more of the islands in a given year. Of the 21 yrs surveyed, foxes were present in 11 yrs (Robertson and Elliot 2002, Lavers 2007, unpublished data). Therefore, we assumed that a fox will be present on at least one of the islands once out of every 2 yrs. Birkhead and Nettleship (1995) estimated that 2555 Razorbill crevices were abandoned in 1992 due to the presence of foxes. Five adult Razorbills were also found depredated by foxes (Birkhead and Nettleship 1995). The data presented by Birkhead and Nettleship (1995) likely overestimate the average number of breeding sites depredated or abandoned in a given year because foxes were present on three of the six islands in 1992. I. L. Jones, J. W. Chardine, and R. D. Elliot visited GC2 and GC4 in 1995 and found foxes present, breeding sites abandoned, and many corpses of adult Razorbills (personal observations). To determine the potential number of nests lost due to a fox in an average year, when foxes are located on only one of the six islands, we estimated the mean number of Razorbill crevices to be 1635 , based on counts for each of the six islands 
Table 1. Reports of razorbills shot accidentally in the Newfoundland and Labrador murre hunt, 1981-2008.

\begin{tabular}{llccccc}
\hline \hline Date & Location & $\begin{array}{c}\text { Razorbills } \\
\text { shot } \\
\text { banded }\end{array}$ & $\begin{array}{c}\text { Razorbills } \\
\text { shot } \\
\text { unbanded }\end{array}$ & $\begin{array}{c}\text { Murres } \\
\text { shot }\end{array}$ & $\begin{array}{c}\text { Razorbill } \\
\text { bycatch (\%) }\end{array}$ & Source \\
\hline November 1981 & Newfoundland & 4 & 277 & 1.4 & Gaston et al. 1983 \\
October 2004 & Labrador & 2 & 18 & 10 & anonymous hunter \\
October 2005 & Labrador & 2 & 35 & 70 & 2.7 & S. Gilliland, pers. comm. \\
November 2006 & Newfoundland & 2 & & 19 & 5 & anonymous hunter \\
October 2008 & Newfoundland & & & & $4.5^{\dagger}$ & \\
Mean & & & & & &
\end{tabular}

${ }^{\dagger}$ Razorbill bycatch during 2004-2008 (weighted average).

in the cluster. Assuming that all crevices on an island are abandoned or predated when a fox is present, this results in a $17 \%$ (1635/9808 breeding pairs = $0.167)$ reduction in the breeding population. Razorbill productivity on islands with no foxes was estimated at 0.390 during 2004-2006 (Lavers and Jones 2007) and modeled as 0.306 chicks fledging per pair, with a reduction of $0.167 * 0.5$ to incorporate foxes in every second year.

\section{Mortality Due to Hunting}

Recoveries of Razorbills banded on the Gannet Islands from 1996-2008 were examined to determine age structure and any temporal or spatial bias in the distribution of the recoveries.

Few qualitative or quantitative estimates of Razorbill bycatch exist. An analysis of band recoveries for Razorbills banded in Quebec during 1925-1994 suggested that several hundred to thousands of Razorbills were shot in the hunt each year (Chapdelaine 1997). The limited data presented in Table 1 suggest that $4.5 \%$ of birds shot during the murre hunt each year are Razorbills. This value is similar to Elliot's (1991) estimate, based on interviews with hunters, of approximately $5 \%$ Razorbill bycatch.

The total annual harvest of murres in Newfoundland and Labrador was estimated to be 173000 during
2001-2003 (Canadian Wildlife Service, unpublished data). Using the mean Razorbill bycatch estimate of $4.5 \%$ (Table 1), the number of Razorbills shot during the hunt is estimated to be $8131 / \mathrm{yr}$. However, not all of these birds would have originated from the Gannet Islands. The Gannet Islands population accounts for approximately $26 \%$ of the North American population, suggesting that as many as 2159 Gannet Islands Razorbills are shot annually.

\section{Population Model}

Razorbills exhibit a life-history strategy typical of most long-lived seabirds, with low fecundity, high adult survival, and delayed breeding. Razorbill demographic parameters were estimated on the Gannet Islands and Machias Seal Island during 1995-2008 and are presented in Table 2. Using these values, we developed a stochastic, age-structured, post-breeding, Lefkovitch population-projection matrix similar to that used by Wiese et al. (2004) for Thick-billed Murres. The computer model written in Matlab version 7.5.0 (MathWorks 2007) consisted of eight age classes, and only females were considered. Productivity parameters in Table 2 were divided by 0.5 , assuming a $1: 1$ sex ratio. Based on age-at-first-breeding data for the Gannet Islands and Machias Seal Island, we define breeding birds as 4 yrs and older (Lavers et al. 2008a). Stochasticity in the demographic rates was modeled by running the projection 500 times, with each vital rate calculated 
Table 2. Summary of the demographic parameters $( \pm S E)$ used for the post-breeding population model for razorbills breeding in Atlantic Canada, 1995-2008. Productivity is the mean number of young fledged per pair.

\begin{tabular}{lccc}
\hline \hline Parameter & Gannet Islands & Machias Seal Island & Sources \\
\hline Population size (breeding pairs) & 9808 & 550 & 2,3 \\
Juvenile survival (age 0-2) & $0.482 \pm 0.033$ & $0.778 \pm 0.041$ & 6 \\
Annual survival (age 3-6) & $0.970 \pm 0.030$ & $0.912 \pm 0.052$ & 6 \\
Annual adult survival (age 7+) & $0.890 \pm 0.053$ & $0.967 \pm 0.028$ & 6 \\
Age at first breeding (yrs) & $4.40 \pm 0.130$ & $3.88 \pm 0.130$ & 5 \\
Proportion of breeders & & & \\
1 yr old & 0.00 & 0.00 & 5 \\
2 yrs old & 0.04 & 0.02 & \\
3 yrs old & 0.25 & 0.32 & \\
4 yrs old & 0.49 & 0.83 & \\
5 yrs old & 0.73 & 0.94 & this study \\
6 yrs old + & 1.00 & 1.00 & \\
Productivity & $0.390 \pm 0.055$ & $0.562 \pm 0.041$ & 0 \\
Hunting mortality & $2159^{\dagger}$ & 0 & \\
\hline
\end{tabular}

${ }^{1}$ Bowser et al. 2009, ${ }^{2}$ Chapdelaine et al. 2001, ${ }^{3}$ Grecian 2005, ${ }^{4}$ Lavers and Jones 2007, ${ }^{5}$ Lavers et al. $2008 a,{ }^{6}$ Lavers et al. $2008 b$.

$\dagger$ Approximate number of razorbills shot from the Gannet Islands based on the number of murres harvested in 2001-2003.

as its mean adjusted by its standard error multiplied by a normally distributed random deviate. Mean $\lambda$ and error were extracted from the distribution of the $500 \lambda$ s from each run of the model.

The effects of anthropogenic mortality and, in this case, fox predation, can be determined by comparing survival rates between affected and unaffected populations (Wiese et al. 2004). However, few populations are unaffected by anthropogenic mortality and, therefore, studies comparing affected and unaffected populations are rare. For this study, we were fortunate to have demographic data for a putative unaffected
Razorbill population on Machias Seal Island. No hunting recoveries from this colony have ever been reported and the colony is more than $600 \mathrm{~km}$ southwest of Newfoundland waters where the hunt occurs. Therefore, we could quantify the effects of hunting mortality on survival by comparing rates on the Gannet Islands with those on Machias Seal Island.

We evaluated the individual and cumulative effects of hunting mortality and Arctic fox predation on population dynamics in two phases. First, we determined the "current conditions" growth rates for the affected Gannet Islands Razorbill 
Figure 1. Seasonal distribution of recoveries of banded razorbills $(n=27)$ from the Gannet Islands, Labrador shot during the murre hunt, 1996-2008.

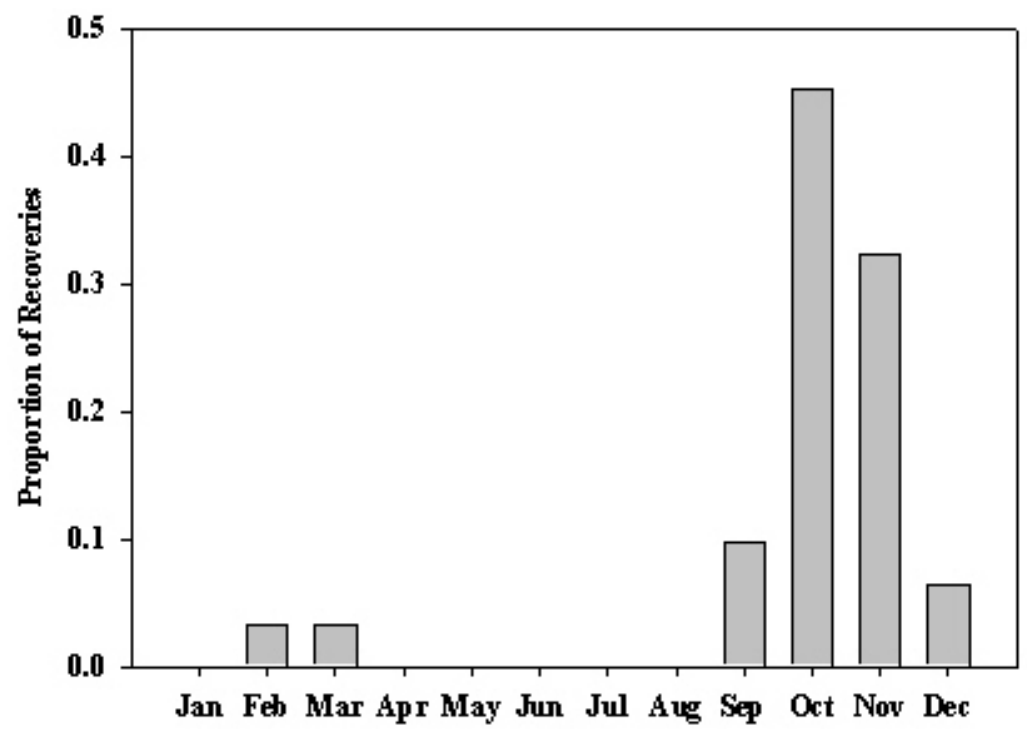

populations and the unaffected Machias Seal Island Razorbill populations using vital rates estimated during 1995-2008. We determined the stable age distribution, the elasticity matrix, and the intrinsic growth rate for all stochastic matrices $(\lambda$; Caswell 2001 ). We chose a 20 -yr time interval as it is most relevant from a management perspective and allowed us to overlook density-dependent processes associated with long-term projections (Morris and Doak 2002, Wiese et al. 2004). We used an elasticity analysis of the matrix-projection models to identify the vital rate that had the largest proportional impact on the population growth rate (McDonald and Caswell 1993, Morris and Doak 2002).

In phase two, we examined the impact of fox predation and hunting mortality on the Gannet Islands Razorbill population dynamics. We did this by incorporating a $16.7 \%$ reduction in productivity in every second yr due to the presence of a fox and comparing the population growth rate to the "baseline" model, i.e., where there was no hunting or foxes. In the absence of hunting mortality, we assumed that juvenile survival on the Gannet Islands would be similar to Machias Seal Island, i.e., no hunting effect. Therefore, to estimate the effect of hunting, we substituted the Gannet Islands juvenilesurvival rate with the Machias Seal Island juvenilesurvival rate. We then estimated the number of birds that had to be removed each year, i.e., killed in the hunt, using the observed age distribution for recoveries to lower the population growth rate back to the "current conditions" growth rate. Relative decreases in the population growth caused by each mortality factor as well as the cumulative effects of both impacts were calculated.

Finally, to validate the model, we used data from three additional studies that examined Razorbill productivity on the Gannet Islands during 19801983, 1997, and 2001-2002 and that reported substantially higher values, ranging from 0.470.85 , compared with the current estimate of 0.39 for 2004-2006 (Birkhead and Nettleship 1983, Hipfner and Bryant 1999, Paredes et al. 2006). Using the current survival and age-at-first-breeding estimates presented in Table 2, we ran a model that incorporated the higher productivity values from these past studies to determine if the observed population trends during 1980-2002 could be replicated by the model.

\section{RESULTS}

\section{Egg-Count Data and Trends}

From 1978-2007, there was no overall trend in the number of eggs counted in the permanent eggmonitoring plots (Table 3 ) as the estimate was 1.000 \pm 0.011 (95\% CI: 0.978-1.022;). The historical trend (1978-1999) suggested a modest decline of 0.985 
Table 3. Number of occupied breeding sites in permanent razorbill study plots on the Gannet Islands, Labrador, 1978-2007 (data up to 1999; Robertson and Elliot 2002).

\begin{tabular}{lccccccccccc}
\hline \hline Plot & 1978 & 1983 & 1984 & $1992^{\dagger}$ & $1998^{\ddagger}$ & 1999 & 2003 & 2004 & $2005^{\ddagger}$ & 2006 & $2007^{\S}$ \\
\hline GC1-a & - & 120 & 134 & - & 153 & 124 & - & - & - & - & 126 \\
GC1-b & - & 110 & 113 & 121 & 165 & 126 & - & - & - & - & 143 \\
GC2-a & 125 & 118 & 123 & 0 & 37 & 55 & 36 & 33 & 28 & 39 & 40 \\
GC2-b & 23 & 32 & 30 & 0 & 13 & 21 & 15 & 18 & 13 & 19 & 14 \\
GC2-c & 92 & 93 & 108 & 0 & 55 & 70 & 57 & 50 & 65 & 59 & 79 \\
GC2-d & - & 46 & 50 & 0 & 23 & 25 & 81 & 78 & 73 & 87 & 98 \\
GC2-e & - & 52 & 53 & 0 & 26 & 37 & 43 & 45 & 46 & 61 & 59 \\
GC3-a & - & 56 & 43 & 22 & 55 & 44 & - & 102 & - & 110 & 100 \\
GC4-a & - & 45 & 32 & 7 & 36 & 46 & - & - & - & - & 77 \\
GC5-a & - & - & 27 & 0 & 21 & 54 & 75 & - & 0 & 81 & 91 \\
GC5-b & - & - & - & - & - & 109 & 129 & - & 0 & 119 & 114 \\
\hline
\end{tabular}

${ }^{\dagger}$ Foxes present on GC2 and GC5, evidence of foxes on GC4

*Fox present on GC5

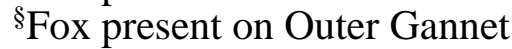

$\pm 0.015(0.957-1.014)$ but recent trends (1998$2007)$ indicate a modest increase of $1.024 \pm 0.026$ (0.976-1.076). However, it must be noted that all three estimates bound 1.000 .

\section{Razorbill Recoveries}

We obtained band recoveries for 29 Razorbills banded as chicks on the Gannet Islands and two birds banded as adults during 1996-2008. Nineteen of the recoveries were direct, i.e., the banded bird was killed or found dead before, during, or immediately following the first period of migratory movement following banding and before return migration would likely have occurred (Gustafson et al. 1997). The month or location of recovery was not known for three of these birds, therefore, they are excluded from the data set. Ninety-three percent of Razorbill recoveries $(n=29)$ occurred between September-December (Fig. 1). Overall, first-yr birds were recovered more frequently than birds 2 yrs of age or older (Table 4). Mean age of recovery was $416 \pm 126$ days $(n=28)$. The age structure of Razorbill recoveries reported during 1996-2008 was not significantly different from Chapdelaine (1997) for $1925-1994\left(\chi^{2}=2.812, p=0.245\right.$; Table 4).

\section{Current Conditions and Baseline Projections for Comparison}

The intrinsic growth rates of the stochastic matrix for the Gannet Islands and Machias Seal Island using current demographic-parameter estimates for each population were $\lambda=0.957 \pm 0.008$ and $\lambda=1.058$ \pm 0.005 respectively (Table 5). Assuming stable age distribution, $57 \%$ of individuals in the Gannet Islands and Machias Seal Island populations were breeders. Proportional changes, that is, elasticity, in survival of breeding birds $(7+$ yrs of age) had the 
Table 4. Recoveries of razorbills shot in the murre hunt with respect to age, 1925-2008.

\begin{tabular}{lcccccc}
\hline \hline Yrs & \multicolumn{2}{c}{$0-1$ yr } & \multicolumn{2}{c}{$2-4$ yrs } & \multicolumn{2}{c}{$5+$ yrs } \\
& $\#$ & $\%$ & $\#$ & $\%$ & $\#$ & $\%$ \\
\hline $1925-1994^{\dagger}$ & 52 & 60 & 30 & 34 & 5 & 6 \\
$1996-2008^{\ddagger}$ & 18 & 62 & 7 & 24 & 4 & 14 \\
\hline
\end{tabular}

${ }^{\dagger}$ Chapdelaine 1997

*This study

largest influence on population trends, being 0.594 for the Gannet Islands and 0.513 for Machias Seal Island (Table 6). Juvenile survival (0-2 yrs), annual survival of birds aged 3-6 yrs, and productivity all had a weaker influence on $\lambda$ compared with adult survival (Table 6).

Using the mean of the past three productivity estimates (Birkhead and Nettleship 1983, Hipfner and Bryant 1999, Paredes et al. 2006), the Gannet Islands Razorbill population was predicted to decrease by $2.7 \% / \mathrm{yr}(\lambda=0.973 \pm 0.002)$. In the absence of hunting mortality and fox predation, the population would be expected to increase very slowly, by $\lambda=1.007 \pm 0.007 / \mathrm{yr}$ (Table 5).

\section{Mortality Due to Foxes}

Predation by Arctic foxes on the Gannet Islands is predicted to reduce the population growth rate by $0.017 \%$ to $0.990 \pm 0.007$ (Table 5).

\section{Mortality Due to Hunt}

To estimate the number of Razorbills shot from the Gannet Islands each year, we substituted the Machias Seal Island juvenile-survival rate into the "current conditions" model (Table 5) and then removed birds from the population to simulate a harvest until we obtained an equivalent growth rate to that estimated for "current conditions" $(\lambda=$ $0.957)$. We determined that 1680 individuals must be shot per year to lower the growth rate back to 0.957 .

\section{DISCUSSION}

\section{Model Assumptions}

In our models, we assumed that Razorbill populations on the Gannet Islands and Machias Seal Island were not near carrying capacity and, therefore, that density-dependent factors were not limiting the populations. Here, we provide evidence to support this assumption. Census data for the Gannet Islands Razorbill population indicate that the population increased from approximately 6497 pairs in 1978 to 9808 pairs in 1999 (Robertson and Elliot 2002). However, an analysis of the egg-count data suggests a stable or slowly declining population over the same time period $(\lambda=0.985$, but confidence limits bound 1.00). Furthermore, during 20032006, Razorbills bred at unusually low densities at some sites (see Table 3, plots GC2a, b, and c) and sites that appeared to be suitable for breeding sites, based on occupation in previous years, were unoccupied (J. L. Lavers, personal observation). Regionally, other islands and colonies near the Gannet Islands also appear to have suitable breeding habitat available (J. L. Lavers and G. J. Robertson, personal observations). In the Gulf of Maine, Razorbill populations were locally extirpated and have only recently begun to recover (Hipfner and Chapdelaine 2002, Lavers 2007) and all populations are small, numbering <800 pairs. We believe these observations support the assumption that the North American Razorbill population is not currently at carrying capacity. Therefore, density-dependent processes at breeding sites and at sea are likely not a concern in the short term. It is possible that Razorbills breeding on Machias Seal Island may begin to experience density-dependent effects in the 
Table 5. Stochastic growth rates for six models projected over 20 yrs. Subscripts reflect different factors in the model $(\mathrm{Sj}=$ juvenile survival (age 0-2), S3-6 = annual survival for birds age 3-6 yrs, Sa $=$ adult survival (age $7+\mathrm{yrs}$ ), $\mathrm{Pa}=$ mean number of young fledged per pair, $\lambda=$ intrinsic rate of increase, $\mathrm{t}=$ time in yrs). Effect is calculated as the difference in a scenario's growth rate relative to the Gannet Islands baseline growth rate.

\begin{tabular}{|c|c|c|c|c|c|c|c|c|c|}
\hline Site & Scenario & Hunting & Fox & $S_{j}$ & $S_{3-6}$ & $S_{a}$ & $P_{a}$ & $\lambda$ & Effect ${ }^{l}$ \\
\hline \multirow[t]{4}{*}{ Gannet Islands } & $\begin{array}{l}\text { Baseline (no hunting/ } \\
\text { foxes) }\end{array}$ & - & - & $0.778^{\dagger}$ & 0.970 & 0.890 & 0.390 & $1.007 \pm 0.007$ & - \\
\hline & Current conditions & $\mathrm{Y}$ & $\mathrm{Y}$ & 0.482 & 0.970 & 0.890 & $0.306^{\ddagger}$ & $0.957 \pm 0.008$ & -0.050 \\
\hline & Fox predation only & - & $\mathrm{Y}$ & $0.778^{\dagger}$ & 0.970 & 0.890 & $0.306^{\ddagger}$ & $0.990 \pm 0.007$ & -0.017 \\
\hline & $P_{\dagger}$ during 1980-2002 & $\mathrm{Y}$ & $\mathrm{Y}$ & 0.482 & 0.970 & 0.890 & $0.615^{\S}$ & $0.973 \pm 0.002$ & - \\
\hline $\begin{array}{l}\text { Machias Seal } \\
\text { Island }\end{array}$ & Current conditions & - & - & 0.778 & 0.912 & 0.967 & 0.562 & $1.058 \pm 0.005$ & - \\
\hline
\end{tabular}

$\dagger$ Juvenile survival estimate from Machias Seal Island (population not exposed to hunting).

$\ddagger$ Fox predation reduced annual productivity from $0.390-0.306$ (see text for explanation).

$\S$ Productivity (0.698 when foxes absent, 0.615 when present) for the Gannet Islands 1980-2002.

lChange in lambda for each scenario relative to the baseline.

next 20 yrs based on the population trajectory. However, this will depend on whether birds from Machias Seal Island continue to disperse and recruit to adjacent islands in the Gulf of Maine (Lavers et al. 2007).

A critical assumption in the construction of demographic models concerns whether harvest mortality is compensatory or additive (Aebischer et al. 1999, Moller 2006). Anthropogenic mortality, i. e., hunting, is in some cases at least partially additive to natural mortality and is responsible for slowed growth or decline of populations (Wiese et al. 2004, Moller 2006). However, the extent to which hunting is additive can depend on a number of factors, including the timing and intensity of the hunt as well as age of the birds taken (Ebbinge 1991, Madsen and Fox 1995, Dehorter and Tamisier 1998, Kokko 2001). For long-lived species, most hunting is probably additive due to the already inherently high survival rates (Gauthier et al. 2001). The compensatory-mortality hypothesis assumes that hunting kills the "doomed surplus." In other words, hunting removes individuals from the population that would die anyway due to density-dependent processes typical of populations near carrying capacity (Nichols 1991, Boyce et al. 1999). However, the observed $30 \%$ difference in juvenile survival between the Gannet Islands and Machias Seal Island (Table 2) is extremely large and hard to explain on the basis of the compensatory-mortality hypothesis, given that neither population appears to be near carrying capacity (Nichols 1991).

\section{Fox Predation}

The deliberate introduction and natural invasion of foxes on islands free of mammalian predators can have devastating and long-lasting effects on seabird colonies (Larson 1960, Petersen 1982, Bailey and Kaiser 1993). Over the last 30 yrs, Arctic foxes that crossed the winter ice to the Gannet Islands have had severe impacts, killing adult Razorbills and markedly reducing the number of breeding attempts (Birkhead and Nettleship 1995, J. L. Lavers and I. L. Jones, personal observations). Results from the model suggest that the presence of foxes on the 
Table 6. Gannet Islands (a) and Machias Seal Island (b) elasticity matrices.

\begin{tabular}{llllllll}
\hline \hline & & & (a) & & \\
\hline 0 & 0 & 0 & 0 & 0.0024 & 0.0019 & 0.0041 & 0.0443 \\
0.0527 & 0 & 0 & 0 & 0 & 0 & 0 & 0 \\
0 & 0.0527 & 0 & 0 & 0 & 0 & 0 & 0 \\
0 & 0 & 0.0527 & 0 & 0 & 0 & 0 & 0 \\
0 & 0 & 0 & 0.0527 & 0 & 0 & 0 & 0 \\
0 & 0 & 0 & 0 & 0.0503 & 0 & 0 & 0 \\
0 & 0 & 0 & 0 & 0 & 0.0484 & 0 & 0 \\
0 & 0 & 0 & 0 & 0 & 0 & 0.0443 & 0.5936 \\
\hline
\end{tabular}

\begin{tabular}{llllllll}
\hline \hline 0 & & & $(\mathrm{~b})$ & & \\
\hline 0.0651 & 0 & 0 & 0 & 0.0063 & 0.0051 & 0.0044 & 0.0494 \\
0 & 0 & 0 & 0 & 0 & 0 & 0 & 0 \\
0 & 0.0651 & 0 & 0 & 0 & 0 & 0 & 0 \\
0 & 0 & 0.0651 & 0 & 0 & 0 & 0 & 0 \\
0 & 0 & 0 & 0.0651 & 0 & 0 & 0 & 0 \\
0 & 0 & 0 & 0 & 0.0588 & 0 & 0 & 0 \\
0 & 0 & 0 & 0 & 0 & 0.0537 & 0 & 0 \\
\hline
\end{tabular}

Gannet Islands may result in a $1.7 \%$ decrease in the predicted population growth rate. This reduction is likely underestimated, as our model did not incorporate any adult Razorbill mortality as a result of fox predation, even though this was observed in 1992 and 1995. Nor did it account for years when foxes are present on more than one island in the cluster. In the Baltic, the invasion of feral mink (Mustela vison) led to a drastic decrease in the number of Razorbill colonies and resulted in an almost complete redistribution of the colonies as birds moved to increasingly remote, mink-free islands (Nordstrom and Korpimaki 2004). Fortunately, the removal of mammalian predators, including foxes, has been shown to significantly increase breeding success and growth rates of many seabird populations (Cooper and Fourie 1991, Bailey and Kaiser 1993). However, on the Gannet Islands, removal of the foxes poses an ethical issue as the foxes are native and arrive on the islands naturally. The islands are listed as an Ecological Reserve under the Wilderness and Ecological 
Figure 2. Location of recoveries of razorbills $(n=27)$ banded on the Gannet Islands $(\bullet)$ during 19962008. Sample sizes are indicated in brackets for sites where more than one bird was recovered.

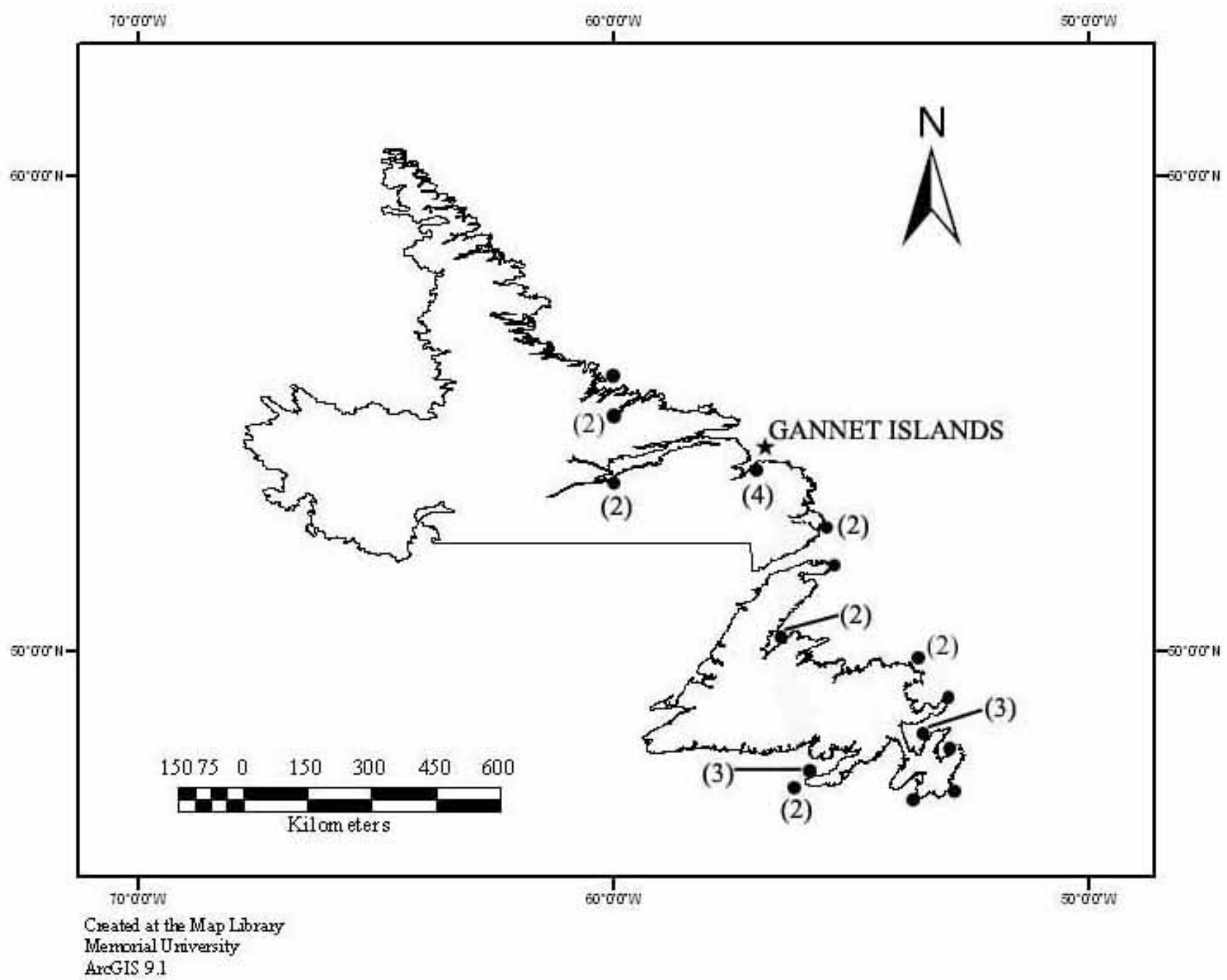

Reserves Act and the removal of the foxes is prohibited under current regulations; however, it can be permitted for conservation purposes.

\section{Hunting Mortality}

Gannet Islands Razorbill recoveries reported by Chapdelaine (1997) from 1925-1960 included two birds from the Gannet Islands that were recovered in the Gulf of St. Lawrence, Quebec, suggesting some movement through this area. However, from 1960-1994, Chapdelaine (1997) did not report further recoveries in the Gulf of St. Lawrence and all Razorbill recoveries from the Gannet Islands from 1996-2008 were made along the east coast of Newfoundland and Labrador (Fig. 2). All but one of the birds recovered in Labrador $(n=11)$ were shot in the first 2 wks of October, suggesting that some birds remain in the area for up to 2 mo 
following fledging. Recoveries of the 22 remaining birds are primarily concentrated along the southeastern tip of Newfoundland, suggesting that Razorbills breeding in Labrador follow a southward movement along the east coast of Newfoundland to their wintering grounds (Fig. 2). However, when interpreting the recoveries, consideration must be given to any spatial or temporal bias in the timing and route of migration in relation to areas of high and low hunting pressure (Chapdelaine 1997). Hunting of seabirds is widespread throughout Newfoundland and Labrador, however, the human population is heavily biased toward eastern Newfoundland. No additional effort was made to obtain band recoveries in western Newfoundland during this period. We expect that the number of Razorbill recoveries is likely low because hunters are aware that it is illegal to shoot Razorbills and thus avoid turning in bands (Gaston et al. 1983, J. L. Lavers and I. L. Jones, personal observation). After four field seasons in Labrador, J. L. Lavers was able convince a small number of hunters to turn in their Razorbill bands on the condition that they could remain anonymous.

In general, young and inexperienced murres and Razorbills are at the greatest risk from hunting (Table 6), even though they represent only $20 \%$ of the population (Chapdelaine 1997, Chardine et al. 2008). It has been suggested that young birds may winter closer to the coast, thus exposing them to hunting (Falk and Durink 1992, Chapdelaine 1997). Our data support this idea, as $62 \%$ of birds recovered from 1996-2008 were less than $1 \mathrm{yr}$ of age and only 11 adult birds in the age range of 434-2656 d were recovered. Furthermore, nine birds were less than 3 mo of age when shot and, therefore, are presumed to have been flightless and more vulnerable to hunters. Note that the growth of primary feathers continues for up to 3 mo post-fledging while at sea (Gaston and Jones 1998).

The current Gannet Islands population growth rate $(\lambda=0.957)$ predicts a declining population in the absence of immigration. This decline is in contrast to the stable population trend suggested by the 1978-2007 egg-count data $(\lambda=1.000)$. There are a number of plausible explanations. First, recruitment of individuals from other nearby populations is not considered in the model due to a lack of quantitative information on dispersal rates. However, there is significant qualitative evidence to support dispersal as a key factor influencing this population (Lavers et al. 2007). In Quebec, some Razorbill populations increased by more the $170 \%$ during 1998-2005, with annual growth rates of $24.3 \%-28.7 \%$ that are clearly not attainable without immigration (Rail and Cotter 2007). Overall, the role of dispersal in maintaining populations with low survival and productivity is widely accepted (Divoky and Horton 1995, Boyd 2002, Oro and Ruxton 2002). Second, if low productivity rates are typical only in recent years, as appears to be the case at both sites (Lavers and Jones 2007), reduced recruitment to the population and thus lower egg counts may take several years to detect because most Razorbills will not return to breed on the Gannet Islands until 4 yrs of age (Lavers et al. 2008a).

In contrast with the Gannet Islands Razorbill population, the Machias Seal Island Razorbill population is predicted to increase at around $6 \% / \mathrm{yr}$ (Table 5) from the current 550 pairs to an estimated 3059 pairs in the next 20 yrs. Machias Seal Island is a small island and is likely not capable of sustaining a Razorbill population of this size. Razorbill band resightings in the Gulf of Maine suggest that many of the surplus birds from Machias Seal Island are recruiting to other nearby islands (Lavers et al. 2007). Therefore, Machias Seal Island Razorbills may not experience density-dependent effects in the short term.

Model results suggest that low juvenile survival on the Gannet Islands has reduced the Razorbill population growth rate by $3.3 \%$ as a result of mortality in the murre hunt, approximately equivalent to 1680 Razorbills being shot each year. This estimate, a $2 \%$ reduction, is higher than for Thick-billed Murres (Wiese et al. 2004), but is comparable to estimates of $5.6 \%$ for annual oiling mortality in Razorbills (Baillie and Mead 1982) and of $5.7 \%$ for Harlequin Ducks (Histrionicus histrionicus; Esler et al. 2000). When productivity was increased to levels observed during 1980-2002, $\lambda$ increased slightly to 0.973 (Table 5).

The limited data available for Razorbill bycatch suggest that approximately $4.7 \%$ of the murres shot each year are Razorbills (Table 1). This mortality rate of 2159 individuals shot from the Gannet Islands, based on a $4.7 \%$ bycatch rate, is greater than that predicted by the model ( $n=1680$ individuals), suggesting that Razorbill bycatch is probably closer to $3 \%-4 \%$ in most years. Overall, the model is highly sensitive to variation in the amount of hunting mortality, so it is likely imprecise in its estimate of rate of decline, although robust in the 
direction of the trend. Note that all of the models, other than the one with no hunting or fox predation, predict a declining Gannet Islands Razorbill population.

\section{CONCLUSION}

Our estimates (Table 2) of juvenile and adult survival on Machias Seal Island were the highest reported for any Razorbill colony (Lavers et al. $2008 b$ ). In contrast, adult and juvenile survival rates for the Gannet Islands were significantly lower, numbering $7.7 \%$ and $38 \%$, respectively. This is likely due to hunting mortality, but also due to other factors such as dispersal and climate. Although dispersal outside the sampling area is known to influence survival rates (Lebreton et al. 2003), intermittent resighting at neighboring colonies in both Labrador and the Gulf of Maine indicated that the Gannet Islands and Machias Seal Island Razorbill populations exhibit similar levels of dispersal, and it is unlikely that this could account for the large variation in survival rates between colonies (Lavers et al. 2007). Variations in oceanographic and feeding conditions are also known to influence seabird demographic rates (Rindorf et al. 2000, Jones et al. 2002). This is also true for Razorbills (Lavers et al. 2008b). Unfortunately, the extent to which oceanographic conditions influence Razorbill demography is not fully understood and there are insufficient data to directly link changes in productivity or survival to prey availability (Lavers and Jones 2007). As a result, we were unable to account for these factors in our model and some caution is warranted when interpreting the results. We were also unable evaluate the scope or severity of other recognized sources of Razorbill mortality, e.g., fisheries bycatch and oil pollution. (Piatt and Nettleship 1987, Chapdelaine et al. 2001, Benjamins et al. 2008) due to lack of sufficient, recent data.

Overall, combined mortality from foxes and hunting reduced the predicted population growth rate by $5 \%$ (Table 5), a figure that is not sustainable under current conditions. When we increased the productivity estimate to reflect what was observed for the Gannet Islands population during 19802002 , the population growth rate increased to 0.973 , similar to the 0.985 growth rate indicated by the egg-count data during 1978-1999 (Table 5), suggesting that increasing fecundity alone is insufficient to reverse the current predicted population decline. However, determining what is causing the recent drastic reduction in productivity on the Gannet Islands should remain a primary concern for managers because it is biologically feasible for Gannet Islands Razorbills to achieve productivity equivalent to or greater than what has been reported in the past (Birkhead and Nettleship 1983, Hipfner and Bryant 1999, Paredes et al. 2006) and at other colonies (Harris and Wanless 1989, Lyngs 1994). Also, efforts to reduce hunting mortality or other anthropogenic mortality sources will require significant resources and time to modify existing legislation and increase enforcement.

If current conditions persist, the Gannet Islands population may be expected to decline by more than $60 \%$ in the next 20 yrs. Although caution must be taken when interpreting the results of our model, a conservative management approach is warranted, given that the Gannet Islands are home to more than $25 \%$ of the North American Razorbill population. Although census data indicate that small amounts of Razorbill hunting mortality and predation from foxes may have been sustainable throughout the 1980s and 1990s, with deteriorating breeding conditions, the previously reported levels are likely no longer sustainable. Given this new information, the recent termination of the annual 1995-2006 seabird-research program on the Gannet Islands that included monitoring of Arctic fox predation, is of significant concern. To ensure the long-term survival of the Razorbill, some or all of the following actions should be implemented: (1) Increase the level of enforcement and education for murre hunters and re-evaluate the timing and quota of the murre hunt with the objective of reducing the hunt in areas where Razorbills are known to aggregate or migrate through. (2) Continue the longterm Razorbill demographic-monitoring program initiated on the Gannet Islands in 1996, with a special emphasis on measuring productivity and determining why chick mortality is high. (3) Expand monitoring to other colonies in Labrador that have not been surveyed in many years to determine if these populations are exhibiting similar trends. (4) If breeding success does not improve, consider an annual fox removal program on the Gannet Islands. 
Responses to this article can be read online at:

http://www.ace-eco.org/vol4/iss2/art3/responses/

\section{Acknowledgments:}

We would like to thank the many people who assisted with the banding and resighting of thousands of Razorbills over the last 14 years. We would also like to thank the hunters who turned in bands and provided information on the recovery of birds. Special thanks to L. and D. Hamel, T. Elson, and R. Cahill for their invaluable advice and logistical support. Generous financial support for this project was provided by the Atlantic Cooperative Wildlife Ecology Research Network, Leslie Tuck Avian Ecology Award, Northern Scientific Training Program, Canadian Wildlife Federation, and The Seabird Group. This is ACWERN Publication No. UNB-75.

\section{LITERATURE CITED}

Aebischer, N. J., G. R., Potts, and M. Rehfisch. 1999. Using ringing data to study the effect of hunting on bird populations. Ringing and Migration 19:67-81.

Bailey, E. P., and G. W. Kaiser. 1993. Impacts of introduced predators on nesting seabirds in the northeast Pacific. Pages 227-231 in K. Vermeer, K. T. Briggs, K. H. Morgan, and D. Siegel Causey. The status, ecology, and conservation of marine birds on the North Pacific Ocean. Canadian Wildlife Service Special Publication, Ottawa, Ontario, Canada.

Baillie, S. R., and C. J. Mead. 1982. The effects of severe oil pollution during the winter of 19801981 on British and Irish auks. Ringing and Migration 4:33-44.

Benjamins, S., D. W. Kulka, and J. Lawson, J. 2008. Incidental catch of seabirds in Newfoundland and Labrador gillnet fisheries, 2001-2003. Endangered Species Research 5:149-160. [online] URL: http://www.int-res.com/articles/esr2008/5/ n005p149.pdf.
Birkhead, T. R., and D. N. Nettleship. 1983. Studies of alcids breeding at the Gannet Clusters, Labrador, 1980-1983. Canadian Wildlife Service Report Number 125, Ottawa, Ontario, Canada.

Birkhead, T. R., and D. N. Nettleship. 1995. Arctic fox influence on a seabird community in Labrador: a natural experiment. Wilson Bulletin 107:397-412. [online] URL: http://elibrary.unm.edu/sora/Wilson/ v107n03/p0397-p0412.pdf.

Blanchard, K. A. 1984. Seabird harvest and the importance of education in seabird management on the north shore of the Gulf of St. Lawrence. Dissertation. Cornell University, Ithaca, New York, USA.

Boyce, M. S., A. R. E. Sinclair, and G. C. White. 1999. Seasonal compensation of predation and harvesting. Oikos 87:419-426.

Boyd, I. L. 2002. The measurement of dispersal by seabirds and seals: implications for understanding their ecology. Pages 72-88 in J. M. Bullock, R. E. Kenward, and R. S. Hails, editors. Dispersal Ecology. British Ecological Society, London, UK.

Canadian Ice Service. 2006. Seasonal summary for eastern Canadian Waters, winter 2005-2006. Ottawa, Ontario, Canada. [online] URL: http://iceglaces.ec.gc.ca/IS SS EC/East Coast Seasonal S ummary 2005-06 english.pdf.

Caswell, H. 2001. Matrix population models: construction, analysis, and interpretation. Second edition. Sinauer, Sunderland, Massachusetts, USA.

Chapdelaine, G. 1997. Pattern of recoveries of banded Razorbills (Alca torda) in the western Atlantic and survival rates of adults and immatures. Colonial Waterbirds 20:47-54.

Chapdelaine, G., A. W. Diamond, R. D. Elliot, and G. J. Robertson. 2001. Status and population trends of the Razorbill in eastern North America. Canadian Wildlife Service Occasional Paper Number 105, Ottawa, Ontario, Canada.

Chardine, J. W., G. J. Robertson, and H. G. Gilchrist. 2008. Seabird harvest in Canada. Pages 20-29 in F. Merkel and T. Barry. Seabird harvest in the Arctic. Circumpolar Seabird Group (CBird), 
CAFF Technical Report Number 16. CAFF International Secretariat, Akureyri, Iceland.

Cooper, J., and A. Fourie. 1991. Improved breeding success of great-winged petrels (Pterodroma macroptera) following control of feral cats (Felis catus) at subantarctic Marion Island. Bird Conservation International 1:171-175.

Croxall, J. P., and P. Rothery. 1991. Population regulation of seabirds: implications of their demography for conservation. Pages 272-296 in C. M. Perrins, J.-D. Lebreton, and G. J. M. Hirons. Bird population studies: their relevance to conservation and management. Oxford University Press, Oxford, UK.

Cuthbert, R., D. Fletcher, and L. S. Davis. 2001. A sensitivity analysis of Hutton's shearwater: prioritizing conservation research and management. Biological Conservation 100:163-172.

Dehorter, O., and A. Tamisier. 1998. Hunting vulnerability and wintering strategy among waterfowl in Camargue, France. Wildlife Biology 4:13-21. [online] URL: http://www.wildlifebiology. com/Indices/1998+-+Volume+4/Number+1/202/En/.

Divoky, G. J., and M. Horton. 1995. Breeding and natal dispersal, nest habitat loss and implications for marbled murrelet populations. United States Department of Agriculture Forest Service General Technical Report PSW-152. [online] URL: http://w ww.fs.fed.us/psw/rsl/projects/wild/gtr152/chap7.pdf

Ebbinge, B. S. 1991. The impact of hunting on mortality-rates and spatial-distribution of geese wintering in the western Palearctic. Ardea 79:197USDA209. [online] URL: http://ardeajournal. natuurinfo.nl/ardeapdf/a79-210-216.pdf.

Elliot R. D. 1991. The management of the Newfoundland turr hunt. Pages 29-35 in A.J. Gaston and R. D. Elliot. Studies of high latitude seabirds. Volume 2. Conservation biology of the thick-billed murre in the northwest Atlantic. Canadian Wildlife Service, Ottawa, Ontario, Canada.

Esler, C., J. A. Schmutz, R. L. Jarvis, and D. M. Mulcahy. 2000. Winter survival of adult female harlequin ducks in relation to history of contamination by the Exxon Valdez oil spill. Journal of Wildlife Management 64:839-847.

Falk, K., and J. Durink. 1992. Thick-billed murre hunting in west Greenland, 1988-89. Arctic 45:167-178. [online] URL: http://pubs.aina.ucalgary. ca/arctic/Arctic45-2-167.pdf.

Gaston, A. J., R. I. Goudie, D. G. Noble, and A. MacFarlane. 1983. Observations on "turr" hunting in Newfoundland: age, condition, and diet of thick-billed murres (Uria lomvia), and proportions of other seabirds, killed off Newfoundland in winter. Canadian Wildlife Service Progress Notes Number 141, Ottawa, Ontario, Canada.

Gaston, A., and I. L. Jones. 1998. The Auks, Alcidae. Oxford University Press, Oxford, UK.

Gauthier, G., R. Pradel, S. Menu, and J.-D. Lebreton. 2001. Seasonal survival of Greater Snow Geese and the effect of hunting under dependence in sighting probability. Ecology 82:3105-3119.

Grecian, V. D. 2005. The effect of physical and biological parameters on the breeding success of Razorbills (Alca torda) L. 1758 on Machias Seal Island, New Brunswick, in 2000 and 2001. Dissertation. University of New Brunswick, Fredericton, New Brunswick, Canada.

Gustafson, M. E., J. Hildenbrand, and L. Metras. 1997. The North American bird banding manual. Version 1.0. Patuxent Wildlife Research Center, U. S. Geological Survey, Reston, Virginia, USA. [online] URL: http://www.pwrc.usgs.gov/BBL/manual/ manual.htm.

Hamilton, S., and H. Moller. 1995. Can PVA models using computer packages offer useful conservation advice? Sooty shearwater (Puffinus griseus) in New Zealand as a case study. Biological Conservation 73:107-117.

Harris, M. P., and S. Wanless. 1989. The breeding biology of razorbills (Alca torda) on the Isle of May. Bird Study 36:105-114.

Hipfner, J. M., and R. Bryant. 1999. Comparative breeding biology of Guillemots (Uria spp.) and Razorbills (Alca torda) at a colony in the northwest Atlantic. Atlantic Seabirds 1:121-134. 
Hipfner, J. M., and G. Chapdelaine. 2002. Razorbill (Alca torda). In A. Poole and F. Gill, editors. Birds of North America. Number 635. Academy of Natural Sciences, Philadelphia, Pennsylvania, USA, and American Ornithologists Union, Washington, D.C., USA.

Jones, I. L., F. M. Hunter, and G. J. Robertson. 2002. Annual adult survival of Least Auklets (Aves, Alcidae) varies with large-scale climatic conditions of the North Pacific Ocean. Oecologia 133:38-44.

Kokko, H. 2001. Optimal and suboptimal use of compensatory responses to harvesting: timing of hunting as an example. Wildlife Biology 7:141-150.

Lack, D.. 1968. Ecological adaptations for breeding in birds. Oxford University Press, Oxford, UK.

Larson, S. 1960. On the influence of the Arctic fox (Alopex lagopus) on the distribution of Arctic birds. Oikos 11:276-305.

Lavers, J. L. 2007. Cumulative mortality and population parameters for a vulnerable seabird, the Razorbill (Alca torda), in Atlantic Canada. Dissertation. Memorial University of Newfoundland, St. John's, Newfoundland, Canada.

Lavers, J. L., and I. L. Jones. 2007. Factors affecting rates of intraspecific kleptoparasitism and breeding success of the Razorbill at the Gannet Islands, Labrador. Marine Ornithology 35:1-7. [online] URL: http://www.marineornithology.org/P DF/35 1/35 1 1-7.pdf.

Lavers, J. L., I. L. Jones, and A. W. Diamond. 2007. Natal and breeding dispersal of Razorbills (Alca torda) in eastern North America. Waterbirds 30:593-599.

Lavers, J. L., I. L. Jones, and A. W. Diamond. 2008a. Age at first return and breeding of Razorbills (Alca torda) in Atlantic Canada. Waterbirds 31:3034.

Lavers, J. L., I. L. Jones, A. W. Diamond, and G. J. Robertson. 2008b. Annual survival of North American Razorbills (Alca torda) varies with ocean climate indices. Canadian Journal of Zoology 86:51-61. [online] URL: http://rparticle.web-p.cisti.
nrc.ca/rparticle/RpArticleViewer? handler $=$ HandleInitialGet\&journal $=$ cjz\&volume $=86 \&$ calyLang $=$ eng\&media=html\&articleFile=z07-113.pdf.

Lebreton, J.-D., and J. Clobert. 1991. Bird population dynamics, management, and conservation: the role of mathematical modeling. Pages 105-125 in C.M. Perrins, J.-D. Lebreton, and G. J. M. Hirons, editors. Bird population studies: relevance to conservation and management. Oxford University Press, Oxford, UK.

Lebreton, J.-D., J. E. Hines, R. Pradel, J. D. Nichols, and J. A. Spendelow. 2003. Estimation by capture-recapture of recruitment and dispersal over several sites. Oikos 101:253-264.

Lyngs, P. 1994. The effects of disturbance on growth rate and survival of young Razorbills Alca torda. Seabird 16:46-49. [online] URL: http://www .seabirdgroup.org.uk/journals/seabird 16.pdf

Madsen, J., and J. D. Fox. 1995. Impacts of hunting disturbance on waterbirds: a review. Wildlife Biology 1:193-207.

MathWorks. 2007. Matlab 7.5.0. The MathWorks Inc., Natick, Massachusetts, USA.

McDonald, D. B., and H. Caswell. 1993. Matrix methods for avian demography. Current Ornithology 10:139-185.

Merkel, F. R. 2004. Impact of hunting and gillnet fishery on wintering eiders in Nuuk, southwest Greenland. Waterbirds 27:469-479.

Moller, H. 2006. Are current harvests of seabirds sustainable? Acta Zoologica Sinica 52:649-652.

Morris, W. F., and D. F. Doak, editors. 2002. Quantitative conservation biology: theory and practice of population viability analysis. Sinauer, Sunderland, Massachusetts, USA.

Nettleship, D. N., and P. G. H. Evans. 1985. Distribution and status of the Atlantic Alcidae. Pages 54-154 in D. N. Nettleship and T. R. Birkhead, editors. The Atlantic Alcidae: evolution, distribution and biology of the Auks inhabiting the Atlantic ocean and adjacent water areas. Academic Press, Oxford, UK. 
Nichols, J. D. 1991. Responses of North American duck populations to exploitation. Pages 498-525 in C.M. Perrins, J.-D. Lebreton, and G. J. M. Hirons, editors. Bird population studies: relevance to conservation and management. Oxford University Press, Oxford, UK.

Nordstrom, M., and E. Korpimaki. 2004. Effects of island isolation and feral mink removal on bird communities on small islands in the Baltic Sea. Journal of Animal Ecology 73:424-433.

Oro, D., and G. D. Ruxton. 2002. The formation and growth of seabird colonies: Audouin's gull as a case study. Journal of Animal Ecology 70:527-535.

Paredes, R., I. L. Jones, and D. J. Boness. 2006. Parental roles of male and female thick-billed murres and razorbills at the Gannet Islands, Labrador. Behaviour 143:451-481.

Petersen, M. R. 1982. Predation on seabirds by red foxes at Shaiak Island, Alaska. Canadian FieldNaturalist 96:41-45.

Piatt, J. F., and D. N. Nettleship. 1987. Incidental catch of marine birds and mammals in fishing nets off Newfoundland, Canada. Marine Pollution Bulletin 18:344-349.

Rail, J.-F., and R. Cotter. 2007. Sixteenth census of seabird populations in the sanctuaries of the North Shore of the Gulf of St. Lawrence, 2005. Canadian Field-Naturalist 121:287-294.

Ratcliffe, N., G. Pickerell, and E. Brindley. 2000. Population trends of little and Sandwich terns Sterna albifrons and S. sandvicensis in Britain and Ireland from 1969 to 1998. Atlantic Seabirds 2:211226.

Rindorf, A., S. Wanless, and M. P. Harris. 2000. Effects of changes in sandeel availability on the reproductive output of seabirds. Marine Ecology Progress Series 202:241-252. [online] URL: http:// www.int-res.com/abstracts/meps/v202/p241-252/.

Robertson, G. J., and R. D. Elliot. 2002. Population size and trends in seabirds breeding in the Gannet Islands, Labrador. Canadian Wildlife Service Technical Report Series Number 393, Ottawa, Ontario, Canada.
Robertson, G. J., R. D. Elliot, and K. G. Chaulk. 2002. Breeding seabird populations in Groswater Bay, Labrador, 1978 and 2002. Canadian Wildlife Service Technical Report Series Number 394, Ottawa, Ontario, Canada.

Rowe, S., and I. L. Jones. 2000. The enigma of Razorbill Alca torda breeding site selection: adaptation to a variable environment? Ibis 142:324327.

Samelius, G., and R. T. Alisauskas. 2001. Deterring Arctic fox predation: the role of parental nest attendance by lesser snow geese. Canadian Journal of Zoology 79:861-866. [online] URL: htt p://article.pubs.nrc-cnrc.gc.ca/RPAS/RPViewDoc? handler =HandleInitialGet\&calyLang=eng\&journal= cjz\&volume=79\&articleFile=z01-048.pdf.

Sandvik, H., K. E. Erikstad, R. T. Barrett, and N. G. Yoccoz. 2005. The effect of climate on adult survival in five species of North Atlantic seabirds. Journal of Animal Ecology 74:817-831.

SAS Institute Inc. 2004. SAS/STAT® 9.1 User's Guide. Cary, North Carolina, USA.

Southern, W. E., S. R. Patton, L. K. Southern, and L. A. Hanners. 1985. Effects of nine years of fox predation on two species of breeding gulls. Auk 102:827-833. [online] URL: http://elibrary.unm.edu/ sora/Auk/v102n04/p0827-p0833.pdf.

Velando, A., and J. Freire. 2002. Population modeling of European shags (Phalacrocorax aristotelis) at their southern limit: conservation implications. Biological Conservation 107:59-69.

Wiese, F. K., G. J. Robertson, and A. J. Gaston. 2004. Impacts of chronic marine oil pollution and the murre hunt in Newfoundland on thick-billed murre (Uria lomvia) populations in the eastern Canadian Arctic. Biological Conservation 116:205216.

Wilhelm, S. I., S. G. Gilliland, G. J. Robertson, P. C. Ryan, and R. E. Elliot. 2008. Development and validation of a wing key to improve harvest management of alcids in the northwest Atlantic. Journal of Wildlife Management 72:1026-1034. 